Published in final edited form as:

Tuberculosis (Edinb). 2007 August ; 87(Suppl 1): S18-S25.

\title{
Co-infection with human immunodeficiency virus and
}

\section{tuberculosis in Asia}

\author{
Sten Vermund ${ }^{1}$ and Naoki Yamamoto ${ }^{2}$ \\ 1 Institute for Global Health, Vanderbilt University School of Medicine, Nashville, TN, USA \\ 2 AIDS Research Center, National Institute of Infectious Diseases, Tokyo, Japan, Email: nyama@nih.go.jp
}

\begin{abstract}
Asia has had historically high levels of tuberculosis (60\% of the global total) and has experienced a marked rise in HIV seroprevalence (22\% of the global total) in key subpopulations of these highly populous nations. Thus, co-infected patients are a challenge for practitioners and public health workers alike. The U.S.-Japan Cooperative Medical Science Program is spearheading interdisciplinary collaborations in Asia to address the many outstanding research priorities for HIVtuberculosis co-infection. There is an urgency to this agenda for many reasons, including the frequency with which tuberculosis accounts for the death of HIV infected persons in Asia, and the continued rise of multiple drug-resistant Mycobacterium tuberculosis. We review briefly the public health situation in Asia, highlighting research questions from US-Japan-Asian partner joint meetings, and cite salient studies to indicate trends and challenges.
\end{abstract}

\section{Keywords}

tuberculosis; HIV; AIDS; Asia; epidemiology; immune reconstitution syndrome; co-infection

\section{Introduction}

The foremost cause of death due to human immunodeficiency virus (HIV) in developing countries is tuberculosis (TB), responsible for at least $13 \%$, and perhaps $\geq 30 \%$ of all deaths. 1,2 In turn, HIV-induced immunosuppression is a substantial contributor to TB reactivation; one study in Cambodia suggested nearly one-quarter of HIV cases from January 2004-February 2005 had active tuberculosis. ${ }^{3}$ Furthermore, the problem is growing despite the antiretroviral therapy (ART) "roll-out" in developing countries for at least four reasons. First, there is a substantial lag in ART availability compared with the clinical need in Asia. Second, the ongoing high incidence of HIV continually generates a cadre of newly at-risk persons. Third, the increasing age of previously HIV-infected persons increases the risk of Mycobacterium tuberculosis reactivation due to advancing immunosuppression. Fourth, there remain serious program limitations that inhibit application of measures to control and prevent both HIV and TB, e.g., directly observed therapy-short course (DOTS). ${ }^{4-9}$ HIV transmission is expanding to the huge and populous Asian continent rapidly. A metaphor is apt: this is a time when oil (HIV) is poured into the fire (TB infected persons) in Asia.

Correspondance: Sten H. Vermund, MD, PhD, Vanderbilt Institute for Global Health, 2215 Garland Avenue (319 Light Hall), Nashville, TN 37323-0242 USA, Email: sten.vermund@ vanderbilt.edu, Phone: 615-322-9374, FAX: 615-322-9400

Publisher's Disclaimer: This is a PDF file of an unedited manuscript that has been accepted for publication. As a service to our customers we are providing this early version of the manuscript. The manuscript will undergo copyediting, typesetting, and review of the resulting proof before it is published in its final citable form. Please note that during the production process errors may be discovered which could affect the content, and all legal disclaimers that apply to the journal pertain. 
Of an estimated 8.9 million active TB cases worldwide in 2004, the World Health Organization (WHO) estimated that $13 \%$ were in HIV infected persons, perhaps double the proportion of a decade ago (Table). ${ }^{2,10,11}$ This reflects the Asian situation in which more and more TB cases are attributable to HIV co-infection and immunosuppression. ${ }^{12-13}$ In the context of this ongoing challenge in research, as well as in both training and service, the $40^{\text {th }}$ anniversary meeting organizers of the U.S.-Japan Cooperative Medical Science Program (USJCMSP) (Kyoto, Japan, December 2005) chose to highlight this link through a joint symposium is the form of the USJCMSP $10^{\text {th }}$ International Conference on Emerging Infectious Diseases in the Pacific Rim, involving the US-Japan Panels on AIDS ${ }^{14}$ and on Tuberculosis-Leprosy. This article serves to highlight and update selected themes that were highlighted in the conference and that remain potent priorities in the area of co-infection research.

\section{Research questions in HIV-TB}

The synergy of HIV and TB takes several forms (Figure 1). HIV-induced immunosuppression increases the likelihood that quiescent $M$. tuberculosis will reactivate. ${ }^{15}$ The newly active TB patient is now infectious for TB whereas without the HIV co-infection, the patient might have remained uninfectious. TB itself up-modulates the host immune system; an activated T cell that is activated in response to infection from $M$. tuberculosis (or a number of other infections such as helminthes or herpeviruses) produces more HIV than a quiescent cell such that HIV expression increases in the face of co-infections. ${ }^{16}$ Higher HIV viral loads increase the rate of disease progression and also increases HIV infectiousness. ${ }^{17-21}$ It may be that TB infection in the HIV-uninfected person results in activated T cells that are now more susceptible to HIV upon exposure. Hence, prevention and treatment of either infection can be expected to assist in the control of the other. ${ }^{22}$ HIV and TB are clearly synergistic, such that their joint clinical management must be considered an essential component of global primary care and public health, as has been argued for HIV and sexually transmitted infections. $23-28$

An anchor for any joint program of HIV and TB control and prevention is to promptly and accurately identify and discriminate patients who are individually and co-infected. Two points are key in interrupting further spread of HIV-TB: 1) efficient discovery of the patient who should introduce antiretroviral therapy and/or modified DOTS, with longer-than-usual course of antituberculosis drugs; and 2) proper management of the patient after beginning of the treatment such that drug interactions, side effects, the immune reconstitution syndrome and managed well, and that drug adherence is facilitated. HIV programs must screen and treat all discovered TB cases; TB programs must offer HIV counseling and testing with proper bridges to HIV care. WHO seeks to expand DOTS, whose success rate is high when properly implemented for just 6-9 months for each patient. However, none of this is easy in the face of infrastructure and manpower limitations; research is essential to guide us in program evaluations and to offer future improvements.

Many research questions are being addressed in the clinical interface of HIV and TB, 29,30 some of which were highlighted at the $10^{\text {th }}$ International Conference on Emerging Infectious Diseases in the Pacific Rim TB-HIV co-infection symposium. A few of these are listed here:

1. By what molecular and cellular mechanisms do tuberculosis infections upregulate HIV expression? 16

2. What is the nature of the immunological changes induced by HIV infection that permit reactivation of $M$. tuberculosis?

3. In the immunosuppressed, co-infected patient with HIV and TB, what is the optimal approach to treatment in order to avoid the paradoxical worsening of TB through the immune reconstitution syndrome (IRIS)? $31-34$ 
4. What is the extent to which certain antituberculosis and antiretroviral drugs interact such that doses must be modified or selected combinations avoided? $35-39$

5. What innovative TB diagnostics can be developed, such as the Microscopic Observation Drug Susceptibility Assay (MODS), to improve the ability of care providers to identify tuberculosis and its resistant strains rapidly and effectively, especially in settings with suboptimal skin testing, radiologic, microscopic, and/or microbiologic capacities? ${ }^{40-44}$

6. How can we develop vaccines for HIV and for TB? ${ }^{45-52}$

7. How can we develop new classes of drugs for HIV and for TB to address cost, toxicities, and drug-resistant organisms? $33-56$

8. How can we identify recently infected persons even before they mount easily identifiable immune (for HIV) and/or inflammatory (for TB) responses? ${ }^{57-60}$

9. How can we reduce high risk behavior to reduce transmission, such as high risk sex for HIV and alcohol abuse for TB? ${ }^{61-72}$

Additional research questions are in the realm of program implementation:

1. How can TB and HIV programs be integrated to the benefit of the co-infected patient? 73,74

2. How can isoniazid prophylaxis be integrated into HIV therapy regimens? $75-79$

3. How can obstacles to HIV testing and counseling in TB clinics be overcome? ${ }^{74}$

4. What is an approach globally to implement TB resistance surveillance for HIV infected patients who are at highest risk of the emergence of multiple-drug resistant (MDR) and extensive drug resistant (XDR) TB strains? What basic laboratory services can be established and sustained for TB testing in resource-limited, rural settings? ${ }^{41}$

5. How can drug supplies and delivery be guaranteed for both HIV and TB to avoid drug resistance? ${ }^{80-83}$

6. How can successful behavioral and community-organization approaches be applied to maximize drug adherence for both HIV and TB therapy? ${ }^{84-88}$

7. How can contact tracing be developed and sustained in all venues of need. ${ }^{89-94}$

8. What are programs that can integrate institutional TB and HIV control programs (e.g., jails and prisons, orphanages, homeless shelters, long-term mental health facilities, health care facilities) with community programs? Program features should include bridges to community care for persons discharged from institutions, reducing risk to family members who visit loved ones in institutions, and protection of institutional employees. $95-102$

9. How do we train health practitioners adequately in both HIV and TB care and prevention, building on many decades of experience in the TB and leprosy fields, both of which depend on long-term sustenance of antimicrobial therapy? ${ }^{103}$

Global investigators are addressing these and other questions. HIV is far better funded in the research arena than is TB. In the United States, fully $\$ 2.89$ billion (11\%) of the total fiscal year 2007 president's budget (i.e., proposed) for the National Institutes of Health in the US is devoted to HIV/AIDS research and development, for example. ${ }^{104}$ Since TB research is an opportunistice infection, acknowledging the linkages between the two infectious diseases and permitting substantial increases in TB research funding will be beneficial. 


\section{HIV and Tuberculosis Co-Infection in Asia}

Asia is characterized by highly variable HIV transmission patterns. In China, injection drug use (IDU) and commercial sex work (CSW) are driving the HIV epidemic. ${ }^{72}$ In India, IDU is most relevant in the northeast, but heterosexual transmission drives the larger epidemic in south India. 105 Thailand, Vietnam, Burma (Myanmar), Tajikistan, and Pakistan, among others in Asia, have serious IDU problems. ${ }^{106-111}$ Men who have sex with men contribute to risk in Hong Kong, Taiwan, China, Thailand, India, and elsewhere in Asia. ${ }^{112-130}$ Given high background rates of TB, no subgroup with HIV infection can be considered at low TB risk.

TB in Asia tracks with poverty, crowding, poor public health and medical infrastructures, and prisons; it can be controlled with familiar approaches such as DOTS, even in the context of HIV co-infection. ${ }^{131-135}$ HIV-TB co-infection is common in all regions where HIV is most prevalent, and can be extremely high among certain subgroups, such as IDUs and prisoners. Only the higher income nations of Asia are controlling TB adequately.

A principal concern for Asia is its vast population and crowding that works towards efficient TB transmission where public health infrastructures are inadequate for screening, case finding, and successful therapy (Figure 2). ${ }^{136}$ Exacerbated by HIV, TB will continue to be a major cause of mortality and illness in Asia. And since HIV continues to rise in Asia, including China and India that house 2.3 billion (>35\%) of the world's 6.5 million persons, the potential for HIV-TB co-expansion can well be viewed as a looming disaster for Asia. The economics of HIV and TB indicate that their joint control is cost-effective, including tackling the costly challenge of MDR-TB. ${ }^{137-142}$ U.S.-funded efforts to expand the DOTS program in Mexico, Haiti, and the Dominican Republic, among other nations, reduce tuberculosis-related morbidity and mortality among migrants to the United States, producing a net cost savings for the United States. ${ }^{143}$ This may be wise for higher income nations in Asia to consider; their own overseas donor support can help reduce the overall burden of TB in Asia, protecting even the richer nations. This is timely as a new threat faces Asia, the potential emergence of so-called XDRTB, or extensively drug-resistant TB, as has occurred in South Africa. ${ }^{144}$ The theme of HIVTB co-infection will remain a priority for the U.S.-Japan Cooperative Medical Science Program and it seeks to engage a broader Asian constituency for its mission to nurture collaborative scientific work between the United States, Japan, and Asian partners.

\section{Acknowledgements}

This work was supported by the U.S.-Japan Cooperative Medical Science Program. Drs. Vermund and Yamamoto were co-chairs of the US-Japan Panels on AIDS at the time of the December 2005 Kyoto meeting.

\section{References}

1. Zumla A, Malon P, Henderson J, Grange JM. Impact of HIV infection on tuberculosis. Postgrad Med J 2000;76:259-68. [PubMed: 10775277]

2. http://www.who.int/mediacentre/factsheets/fs104/en/index.html\#hiv Accessed February 11, 2007

3. Centers for Disease Control and Prevention. Screening HIV-infected persons for tuberculosis-Cambodia, January 2004-February 2005. MMWR Morb Mortal Wkly Rep 2005;54:1177-80. [PubMed: 16304553]

4. Thanprasertsuk S, Lertpiriyasuwat C, Leusaree T, et al. HIV/AIDS care and treatment in three provinces in northern Thailand before the national scale-up of highly-active antiretroviral therapy. Southeast Asian J Trop Med Public Health 2006;37:83-9. [PubMed: 16771217]

5. Zhang FJ, Pan J, Yu L, Wen Y, Zhao Y. Current progress of China's free ART program. Cell Res 2005;15:877-82. [PubMed: 16354563]

6. Sutthent R, Arworn D, Kaoriangudom S, et al. HIV-1 drug resistance in Thailand: before and after National Access to Antiretroviral Program. J Clin Virol 2005;34:272-6. [PubMed: 16286051] 
7. Puthanakit T, Oberdorfer A, Akarathum N, et al. Efficacy of highly active antiretroviral therapy in HIV-infected children participating in Thailand's National Access to Antiretroviral Program. Clin Infect Dis 2005;41:100-7. [PubMed: 15937769]

8. Punpanich W, Ungchusak K, Detels R. Thailand's response to the HIV epidemic: yesterday, today, and tomorrow. AIDS Educ Prev 2004;16(3):119-36. [PubMed: 15262571]

9. Amornwichet P, Teeraratkul A, Simonds RJ, et al. Preventing mother-to-child HIV transmission: the first year of Thailand's national program. JAMA 2002;288:245-8. [PubMed: 12095391]

10. Corbett EL, Watt CJ, Walker N, et al. The growing burden of tuberculosis: global trends and interactions with the HIV epidemic. Arch Intern Med 2003;163:1009-21. [PubMed: 12742798]

11. Perlman DC, El-Helou P, Salomon N. Tuberculosis in patients with human immunodeficiency virus infection. Semin Respir Infect 1999;14:344-52. [PubMed: 10638514]

12. Chadha VK. Tuberculosis epidemiology in India: a review. Int J Tuberc Lung Dis 2005;9:1072-82. [PubMed: 16229217]

13. Drobniewski FA, Atun R, Fedorin I, Bikov A, Coker R. The 'bear trap': the colliding epidemics of tuberculosis and HIV in Russia. Int J STD AIDS 2004;15:641-6. [PubMed: 15479497]

14. Umenai T, Narula M, Onuki D, Yamamoto T, Igari T. International HIV and AIDS prevention: Japan/ United States collaboration. J Acquir Immune Defic Syndr Hum Retrovirol 1997;14:S58-67. [PubMed: 9070516]

15. Selwyn PA, Hartel D, Lewis VA, et al. A prospective study of the risk of tuberculosis among intravenous drug users with human immunodeficiency virus infection. N Engl J Med 1989;320:54550. [PubMed: 2915665]

16. Villacian JS, Tan GB, Teo LF, Paton NI. The effect of infection with Mycobacterium tuberculosis on T-cell activation and proliferation in patients with and without HIV co-infection. J Infect 2005;51:408-12. [PubMed: 16321653]

17. Fang CT, Hsu HM, Twu SJ, et al. Decreased HIV transmission after a policy of providing free access to highly active antiretroviral therapy in Taiwan. J Infect Dis 2004;190:879-85. [PubMed: 15295691]

18. Cohen MS, Hosseinipour M, Kashuba A, Butera S. Use of antiretroviral drugs to prevent sexual transmission of HIV. Curr Clin Top Infect Dis 2002;22:214-51. [PubMed: 12520656]

19. Fideli US, Allen SA, Musonda R, et al. Virologic and immunologic determinants of heterosexual transmission of human immunodeficiency virus type 1 in Africa. AIDS Res Hum Retroviruses 2001;17:901-10. [PubMed: 11461676]

20. Quinn TC, Wawer MJ, Sewankambo N, et al. Viral load and heterosexual transmission of human immunodeficiency virus type Rakai Project Study Group. N Engl J Med 2000;342:921-9. [PubMed: 10738050]

21. Vernazza PL, Troiani L, Flepp MJ, et al. Potent antiretroviral treatment of HIV-infection results in suppression of the seminal shedding of HIV. The Swiss HIV Cohort Study. AIDS 2000;14:117-21. [PubMed: 10708281]

22. Williams BG, Granich R, Chauhan LS, Dharmshaktu NS, Dye C. The impact of HIV/AIDS on the control of tuberculosis in India. Proc Natl Acad Sci USA 2005;102:9619-24. [PubMed: 15976029]

23. Cohen MS. HIV and sexually transmitted diseases: lethal synergy. Top HIV Med 2004;12:104-7. [PubMed: 15516707]

24. Fleming DT, Wasserheit JN. From epidemiological synergy to public health policy and practice: the contribution of other sexually transmitted diseases to sexual transmission of HIV infection. Sex Transm Infect 1999;75:3-17. [PubMed: 10448335]

25. van Dam CJ. Sexually transmitted diseases and HIV infection: implications for control and prevention. J Indian Med Assoc 1994;92:8-10. [PubMed: 8207284]

26. Risbud A. Human immunodeficiency virus (HIV) and sexually transmitted diseases (STDs). Indian J Med Res 2005;121:369-76. [PubMed: 15817950]

27. Galvin SR, Cohen MS. The role of sexually transmitted diseases in HIV transmission. Nat Rev Microbiol 2004;2:33-42. [PubMed: 15035007]

28. Clottey C, Dallabetta G. Sexually transmitted diseases and human immunodeficiency virus. Epidemiologic synergy? Infect Dis Clin North Am 1993;7:753-70. [PubMed: 8106728] 
29. Vermund SH, Powderly WG. Developing a human immunodeficiency virus/acquired immunodeficiency syndrome therapeutic research agenda for resource-limited countries: A consensus statement. Clin Infect Dis 2003;37:S4-12. [PubMed: 12822127]

30. Zulu I, Schuman P, Musonda R, et al. Priorities for antiretroviral therapy research in Sub-Saharan Africa: A 2002 consensus conference in Zambia. J Acquir Immune Defic Syndr 2004;36(3):831-4. [PubMed: 15213567]

31. Manosuthi W, Kiertiburanakul S, Phoorisri T, Sungkanuparph S. Immune reconstitution inflammatory syndrome of tuberculosis among HIV-infected patients receiving antituberculous and antiretroviral therapy. J Infect 2006;53:357-63. [PubMed: 16487593]

32. Michailidis C, Pozniak AL, Mandalia S, Basnayake S, Nelson MR, Gazzard BG. Clinical characteristics of IRIS syndrome in patients with HIV and tuberculosis. Antivir Ther 2005;10:41722. [PubMed: 15918332]

33. Bonnet MM, Pinoges LL, Varaine FF, et al. Tuberculosis after HAART initiation in HIV-positive patients from five countries with a high tuberculosis burden. AIDS 2006;20:1275-9. [PubMed: 16816556]

34. Wendel KA, Alwood KS, Gachuhi R, Chaisson RE, Bishai WR, Sterling TR. Paradoxical worsening of tuberculosis in HIV-infected persons. Chest 2001;120:193-7. [PubMed: 11451837]

35. Gupta SB, Pujari SN, Joshi SR, Patel AK. AIDS Society of India Guidelines Development Committee. API consensus guidelines for use of antiretroviral therapy in adults (API-ART guidelines). Endorsed by the AIDS Society of India. J Assoc Physicians India 2006;54:57-74. [PubMed: 16649742]

36. Swaminathan S, Luetkemeyer A, Srikantiah P, Lin R, Charlebois E, Havlir DV. Antiretroviral therapy and TB. Trop Doct 2006;36:73-9. [PubMed: 16611437]

37. Di Perri G, Aguilar Marucco D, Mondo A, et al. Drug-drug interactions and tolerance in combining antituberculosis and antiretroviral therapy. Expert Opin Drug Saf 2005;4:821-36. [PubMed: 16111446]

38. Sharma SK, Mohan A, Kadhiravan T. HIV-TB co-infection: epidemiology, diagnosis and management. Indian J Med Res 2005;121:550-67. [PubMed: 15817963]

39. Kwara A, Flanigan TP, Carter EJ. Highly active antiretroviral therapy (HAART) in adults with tuberculosis: current status. Int J Tuberc Lung Dis 2005;9:248-57. [PubMed: 15786886]

40. Shiferaw G, Woldeamanuel Y, Gebeyehu M, Girmachew F, Demessie D, Lemma E. Evaluation of Microscopic Observation Drug Susceptibility Assay (MODS) For the Detection of MultidrugResistant Tuberculosis (MDR-TB). J Clin Microbiol. 2007 Jan 24;Epub ahead of print

41. Moore DA, Evans CA, Gilman RH, et al. Microscopic-observation drug-susceptibility assay for the diagnosis of TB. N Engl J Med 2006;355:1539-50. [PubMed: 17035648]

42. Moore DA, Caviedes L, Gilman RH, et al. Infrequent MODS TB culture cross-contamination in a high-burden resource-poor setting. Diagn Microbiol Infect Dis 2006;56:35-43. [PubMed: 16678991]

43. Moore DA, Mendoza D, Gilman RH, et al. Microscopic observation drug susceptibility assay, a rapid, reliable diagnostic test for multidrug-resistant tuberculosis suitable for use in resource-poor settings. J Clin Microbiol 2004;42:4432-7. [PubMed: 15472289]

44. Park WG, Bishai WR, Chaisson RE, Dorman SE. Performance of the microscopic observation drug susceptibility assay in drug susceptibility testing for Mycobacterium tuberculosis. J Clin Microbiol 2002;40:4750-2. [PubMed: 12454186]

45. Letvin NL. Progress and obstacles in the development of an AIDS vaccine. Nat Rev Immunol 2006;6:930-9. [PubMed: 17124514]

46. Kaufmann SH, Baumann S, Nasser Eddine A. Exploiting immunology and molecular genetics for rational vaccine design against tuberculosis. Int J Tuberc Lung Dis 2006;10:1068-79. [PubMed: 17044198]

47. Wiker HG, Mustafa T, Malen H, Riise AM. Vaccine approaches to prevent tuberculosis. Scand J Immunol 2006;64:243-50. [PubMed: 16918693]

48. Duerr A, Wasserheit JN, Corey L. HIV vaccines: new frontiers in vaccine development. Clin Infect Dis 2006;43:500-11. [PubMed: 16838241]

49. Baumann S, Nasser Eddine A, Kaufmann SH. Progress in tuberculosis vaccine development. Curr Opin Immunol 2006;18:438-48. [PubMed: 16777396] 
50. Skeiky YA, Sadoff JC. Advances in tuberculosis vaccine strategies. Nat Rev Microbiol 2006;4:46976. [PubMed: 16710326]

51. Wiker HG, Mustafa T, Malen H, Riise AM. Vaccine approaches to prevent tuberculosis. Scand J Immunol 2006;64:243-50. [PubMed: 16918693]

52. Fletcher H, McShane H. Tuberculosis vaccines: current status and future prospects. Expert Opin Emerg Drugs 2006;11:207-15. [PubMed: 16634697]

53. Citterio P, Rusconi S. Novel inhibitors of the early steps of the HIV-1 life cycle. Expert Opin Investig Drugs 2007;16:11-23.

54. Tomioka H. Current status of some antituberculosis drugs and the development of new antituberculous agents with special reference to their in vitro and in vivo antimicrobial activities. Curr Pharm Des 2006;12:4047-70. [PubMed: 17100611]

55. Sterjovski J, Churchill MJ, Wesselingh SL, Gorry PR. HIV-1 entry inhibitors: classes, applications and factors affecting potency. Curr HIV Res 2006;4:387-400. [PubMed: 17073614]

56. Biava M, Porretta GC, Deidda D, Pompei R. New trends in development of antimycobacterial compounds. Infect Disord Drug Targets 2006;6:159-72. [PubMed: 16789877]

57. Pai M, Kalantri S, Dheda K. New tools and emerging technologies for the diagnosis of tuberculosis: part I Latent tuberculosis. Expert Rev Mol Diagn 2006;6:413-22. [PubMed: 16706743]

58. Pai M, Kalantri S, Dheda K. New tools and emerging technologies for the diagnosis of tuberculosis: part II Active tuberculosis and drug resistance. Expert Rev Mol Diagn 2006;6:423-32. [PubMed: 16706744]

59. Fiscus SA, Pilcher CD, Miller WC, et al. Rapid, real-time detection of acute HIV infection in patients in Africa. J Infect Dis 2007;195:416-24. [PubMed: 17205481]

60. Pilcher CD, McPherson JT, Leone PA, et al. Real-time, universal screening for acute HIV infection in a routine HIV counseling and testing population. JAMA 2002;288:216-21. [PubMed: 12095386]

61. Liu A, Kilmarx P, Jenkins RA, et al. Sexual initiation, substance use, and sexual behavior and knowledge among vocational students in northern Thailand. Int Fam Plan Perspect 2006;32:126-35. [PubMed: 17015242]

62. Chiao C, Morisky DE, Rosenberg R, Ksobiech K, Malow R. The relationship between HIV/Sexually Transmitted Infection risk and alcohol use during commercial sex episodes: results from the study of female commercial sex workers in the Philippines. Subst Use Misuse 2006;41:1509-33. [PubMed: 17002991]

63. Kizuki M, Takano T, Nakamura K, et al. Social course patterns of urban dwellers with tuberculosis under fragile living conditions in Tokyo, Japan. J Epidemiol 2006;16:167-75. [PubMed: 16837768]

64. Shetty N, Shemko M, Vaz M, D'Souza G. An epidemiological evaluation of risk factors for tuberculosis in South India: a matched case control study. Int J Tuberc Lung Dis 2006;10:80-6. [PubMed: 16466042]

65. Davies PD, Yew WW, Ganguly D, et al. Smoking and tuberculosis: the epidemiological association and immunopathogenesis. Trans R Soc Trop Med Hyg 2006;100:291-8. [PubMed: 16325875]

66. Madhivanan P, Hernandez A, Gogate A, et al. Alcohol use by men is a risk factor for the acquisition of sexually transmitted infections and human immunodeficiency virus from female sex workers in Mumbai, India. Sex Transm Dis 2005;32:685-90. [PubMed: 16254543]

67. Lin D, Li X, Yang H, et al. Alcohol intoxication and sexual risk behaviors among rural-to-urban migrants in China. Drug Alcohol Depend 2005;79:103-12. [PubMed: 15943949]

68. Kaljee LM, Genberg BL, Minh TT, Tho LH, Thoa LT, Stanton B. Alcohol use and HIV risk behaviors among rural adolescents in Khanh Hoa Province Viet Nam. Health Educ Res 2005;20:71-80. [PubMed: 15198997]

69. Sivaram S, Srikrishnan AK, Latkin CA, et al. Development of an opinion leader-led HIV prevention intervention among alcohol users in Chennai, India. AIDS Educ Prev 2004;16:137-49. [PubMed: 15134122]

70. Nakamura Y, Obase Y, Suyama N, et al. A small outbreak of pulmonary tuberculosis in non-close contact patrons of a bar. Intern Med 2004;43:263-7. [PubMed: 15098614]

71. Celentano DD, Bond KC, Lyles CM, et al. Preventive intervention to reduce sexually transmitted infections: a field trial in the Royal Thai Army. Arch Intern Med 2000;160:535-40. [PubMed: 10695694] 
72. Qian HZ, Vermund SH, Wang N. Risk of HIV/AIDS in China: subpopulations of special importance. Sex Transm Infect 2005;81:442-7. [PubMed: 16326842]

73. Jack C, Lalloo U, Karim QA, et al. A pilot study of once-daily antiretroviral therapy integrated with tuberculosis directly observed therapy in a resource-limited setting. J Acquir Immune Defic Syndr 2004;36:929-34. [PubMed: 15220699]

74. Godfrey-Faussett P, Maher D, Mukadi YD, Nunn P, Perriens J, Raviglione M. How human immunodeficiency virus voluntary testing can contribute to tuberculosis control. Bull World Health Organ 2002;80:939-45. [PubMed: 12571721]

75. Colebunders R, Bastian I. A review of the diagnosis and treatment of smear-negative pulmonary tuberculosis. Int J Tuberc Lung Dis 2000;4:97-107. [PubMed: 10694086]

76. Harries AD, Maher D, Nunn P. An approach to the problems of diagnosing and treating adult smearnegative pulmonary tuberculosis in high-HIV-prevalence settings in sub-Saharan Africa. Bull World Health Organ 1998;76:651-62. [PubMed: 10191561]

77. Schneider RF, Rosen MJ. Respiratory infections in patients with HIV infection. Curr Opin Pulm Med 1996;2:246-52. [PubMed: 9363146]

78. Shafer RW, Edlin BR. Tuberculosis in patients infected with human immunodeficiency virus: perspective on the past decade. Clin Infect Dis 1996;22:683-704. [PubMed: 8729208]

79. Vajpayee M, Kanswal S, Seth P, Wig N, Pandey RM. Tuberculosis infection in HIV-infected Indian patients. AIDS Patient Care STDS 2004;18:209-13. [PubMed: 15142351]

80. Dimitrova B, Balabanova D, Atun R, Drobniewski F, Levicheva V, Coker R. Health service providers' perceptions of barriers to tuberculosis care in Russia. Health Policy Plan 2006;21:265-74. [PubMed: 16728512]

81. Borgdorff MW, Floyd K, Broekmans JF. Interventions to reduce tuberculosis mortality and transmission in low- and middle-income countries. Bull World Health Organ 2002;80:217-27. [PubMed: 11984608]

82. Ngamvithayapong J, Yanai H, Winkvist A, Saisorn S, Diwan V. Feasibility of home-based and health centre-based DOT: perspectives of TB care providers and clients in an HIV-endemic area of Thailand. Int J Tuberc Lung Dis 2001;5:741-5. [PubMed: 11495265]

83. Ellner JJ, Hinman AR, Dooley SW, et al. Tuberculosis symposium: emerging problems and promise. J Infect Dis 1993;168:537-51. [PubMed: 8354898]

84. Safren SA, Kumarasamy N, Hosseinipour M, et al. Perceptions about the acceptability of assessments of HIV medication adherence in Lilongwe, Malawi and Chennai, India. AIDS Behav 2006;10:44350. [PubMed: 16604297]

85. Khan MA, Walley JD, Witter SN, Shah SK, Javeed S. Tuberculosis patient adherence to direct observation: results of a social study in Pakistan. Health Policy Plan 2005;20:354-65. [PubMed: 16183735]

86. Balasubramanian R, Garg R, Santha T, et al. Gender disparities in tuberculosis: report from a rural DOTS programme in south India. Int J Tuberc Lung Dis 2004;8:323-32. [PubMed: 15139471]

87. Watkins RE, Rouse CR, Plant AJ. Tuberculosis treatment delivery in Bali: a qualitative study of clinic staff perceptions. Int J Tuberc Lung Dis 2004;8:218-25. [PubMed: 15139451]

88. Rodger AJ, Toole M, Lalnuntluangi B, Muana V, Deutschmann P. DOTS-based tuberculosis treatment and control during civil conflict and an HIV epidemic, Churachandpur District, India. Bull World Health Organ 2002;80:451-6. [PubMed: 12132001]

89. Chee CB, Teleman MD, Boudville IC, Wang YT. Contact screening and latent TB infection treatment in Singapore correctional facilities. Int J Tuberc Lung Dis 2005;9:1248-52. [PubMed: 16333933]

90. Tornee S, Kaewkungwal J, Fungladda W, Silachamroon U, Akarasewi P, Sunakorn P. Factors associated with the household contact screening adherence of tuberculosis patients. Southeast Asian J Trop Med Public Health 2005;36:331-40. [PubMed: 15916038]

91. Tornee S, Kaewkungwal J, Fungladda W, Silachamroon U, Akarasewi P, Sunakorn P. Risk factors for tuberculosis infection among household contacts in Bangkok, Thailand. Southeast Asian J Trop Med Public Health 2004;35:375-83. [PubMed: 15691140]

92. Chee CB, Teleman MD, Boudville IC, Do SE, Wang YT. Treatment of latent TB infection for close contacts as a complementary TB control strategy in Singapore. Int J Tuberc Lung Dis 2004;8:22631. [PubMed: 15139452] 
93. Suggaravetsiri P, Yanai H, Chongsuvivatwong V, Naimpasan O, Akarasewi P. Integrated counseling and screening for tuberculosis and HIV among household contacts of tuberculosis patients in an endemic area of HIV infection: Chiang Rai, Thailand. Int J Tuberc Lung Dis 2003;7(12):S424-31. [PubMed: 14677833]

94. Rahman M, Fukui T, Asai A. Cost-effectiveness analysis of partner notification program for human immunodeficiency virus infection in Japan. J Epidemiol 1998;8:123-8. [PubMed: 9673082]

95. Dolan K, Kite B, Black E, Aceijas C, Stimson GV. Reference Group on HIV/AIDS Prevention and Care among Injecting Drug Users in Developing and Transitional Countries. HIV in prison in lowincome and middle-income countries. Lancet Infect Dis 2007;7:32-41. [PubMed: 17182342]

96. Singh S, Crofts N. HIV infection among injecting drug users in north-east Malaysia, 1992. AIDS Care 1993;5:273-81. [PubMed: 8218462]

97. Carvell AL, Hart GJ. Risk behaviours for HIV infection among drug users in prison. BMJ 1990;300:1383-4. [PubMed: 2372588]

98. Beyrer C, Jittiwutikarn J, Teokul W, et al. Drug use, increasing incarceration rates, and prisonassociated HIV risks in Thailand. AIDS Behav 2003;7:153-61. [PubMed: 14586200]

99. Niveau G. Prevention of infectious disease transmission in correctional settings: a review. Public Health 2006;120:33-41. [PubMed: 16129465]

100. Coninx R, Maher D, Reyes H, Grzemska M. Tuberculosis in prisons in countries with high prevalence. BMJ 2000;320:440-2. [PubMed: 10669453]

101. Reyes H, Coninx R. Pitfalls of tuberculosis programmes in prisons. BMJ 1997;315:1447-50. [PubMed: 9418098]

102. Stead WW. Special problems in tuberculosis. Tuberculosis in the elderly and in residents of nursing homes, correctional facilities, long-term care hospitals, mental hospitals, shelters for the homeless, and jails. Clin Chest Med 1989;10:397-405. [PubMed: 2673648]

103. Reid SE, Reid CA, Vermund SH. Antiretroviral therapy in sub-Saharan Africa: Adherence lessons from tuberculosis and leprosy. Int J STD AIDS 2004;15:713-6. [PubMed: 15537453]

104. http://officeofbudget.od.nih.gov/pdf/Press\%20info\%20final.pdf Accessed February 11, 2007

105. Chandrasekaran P, Dallabetta G, Loo V, Rao S, Gayle H, Alexander A. Containing HIV/AIDS in India: the unfinished agenda. Lancet Infect Dis 2006;6:508-21. [PubMed: 16870529]

106. Vermund SH, White H, Shah SA, et al. HIV/AIDS in Pakistan: has the explosion begun? J Pak Med Assoc 2006;56(1):S1-2. [PubMed: 16689472]

107. Beyrer C, Suwanvanichkij V, Mullany LC, et al. Responding to AIDS, tuberculosis, malaria, and emerging infectious diseases in Burma: dilemmas of policy and practice. PLoS Med 2006;3:e393. [PubMed: 17032061]

108. Stachowiak JA, Tishkova FK, Strathdee SA, et al. Marked ethnic differences in HIV prevalence and risk behaviors among injection drug users in Dushanbe, Tajikistan, 2004. Drug Alcohol Depend 2006;82:S7-14. [PubMed: 16769449]

109. Go VF, Frangakis C, Nam le V, et al. High HIV sexual risk behaviors and sexually transmitted disease prevalence among injection drug users in Northern Vietnam: implications for a generalized HIV epidemic. J Acquir Immune Defic Syndr 2006;42:108-15. [PubMed: 16763499]

110. Cheng Y, Sherman SG, Srirat N, et al. Risk factors associated with injection initiation among drug users in Northern Thailand. Harm Reduct J 2006;3:10. [PubMed: 16536869]

111. Kawichai S, Celentano DD, Vongchak T, et al. HIV voluntary counseling and testing and HIV incidence in male injecting drug users in northern Thailand: evidence of an urgent need for HIV prevention. J Acquir Immune Defic Syndr 2006;41:186-93. [PubMed: 16394851]

112. Setia MS, Lindan C, Jerajani HR, et al. Men who have sex with men and transgenders in Mumbai, India: an emerging risk group for STIs and HIV. Indian J Dermatol Venereol Leprol 2006;72:42531. [PubMed: 17179617]

113. Inoue Y, Yamazaki Y, Kihara M, Wakabayashi C, Seki Y, Ichikawa S. The intent and practice of condom use among HIV-positive men who have sex with men in Japan. AIDS Patient Care STDS 2006;20:792-802. [PubMed: 17134353]

114. Zhou YR. Homosexuality, seropositivity, and family obligations: perspectives of HIV-infected men who have sex with men in China. Cult Health Sex 2006;8:487-500. [PubMed: 17050382] 
115. Gupta A, Mehta S, Godbole SV, et al. Same-sex behavior and high rates of HIV among men attending sexually transmitted infection clinics in Pune, India (1993-2002). J Acquir Immune Defic Syndr 2006;43:483-90. [PubMed: 17019372]

116. Hidaka Y, Ichikawa S, Koyano J, et al. Substance use and sexual behaviours of Japanese men who have sex with men: a nationwide internet survey conducted in Japan. BMC Public Health 2006;6:239. [PubMed: 17002800]

117. Khan SI, Hudson-Rodd N, Saggers S, Bhuiya A. Men who have sex with men's sexual relations with women in Bangladesh. Cult Health Sex 2005;7:159-69. [PubMed: 16864195]

118. Hernandez AL, Lindan CP, Mathur M, et al. Sexual behavior among men who have sex with women, men, and Hijras in Mumbai, India--multiple sexual risks. AIDS Behav 2006;10:S5-16. [PubMed: 16832600]

119. He Q, Wang Y, Lin P, et al. Potential bridges for HIV infection to men who have sex with men in Guangzhou, China. AIDS Behav 2006;10:S17-23. [PubMed: 16802197]

120. Mansergh G, Naorat S, Jommaroeng R, et al. Inconsistent condom use with steady and casual partners and associated factors among sexually-active men who have sex with men in Bangkok, Thailand. AIDS Behav 2006;10:743-51. [PubMed: 16715348]

121. Wong WC, Zhang J, Wu SC, Kong TS, Ling DC. The HIV related risks among men having sex with men in rural Yunnan, China: a qualitative study. Sex Transm Infect 2006;82:127-30. [PubMed: 16581737]

122. Ko NY, Lee HC, Chang JL, et al. Prevalence of human immunodeficiency virus and sexually transmitted infections and risky sexual behaviors among men visiting gay bathhouses in Taiwan. Sex Transm Dis 2006;33:467-73. [PubMed: 16543861]

123. Choi KH, Lui H, Guo Y, Han L, Mandel JS. Lack of HIV testing and awareness of HIV infection among men who have sex with men, Beijing, China. AIDS Educ Prev 2006;18:33-43. [PubMed: 16539574]

124. Dandona L, Dandona R, Kumar GA, Gutierrez JP, McPherson S, Bertozzi SM. ASCI FPP Study Team. How much attention is needed towards men who sell sex to men for HIV prevention in India? BMC Public Health 2006;6:31. [PubMed: 16478546]

125. Jiang J, Cao N, Zhang J, et al. High prevalence of sexually transmitted diseases among men who have sex with men in Jiangsu Province, China. Sex Transm Dis 2006;33:118-23. [PubMed: 16432484]

126. Zhang BC, Chu QS. MSM and HIV/AIDS in China. Cell Res 2005;15:858-64. [PubMed: 16354560]

127. Thanprasertsuk S, Sirivongrangson P, Ungchusak K, et al. The invisibility of the HIV epidemic among men who have sex with men in Bangkok, Thailand. AIDS 2005;19:1932-3. [PubMed: 16227811]

128. Beyrer C, Sripaipan T, Tovanabutra S, et al. High HIV, hepatitis C and sexual risks among drugusing men who have sex with men in northern Thailand. AIDS 2005;19:1535-40. [PubMed: 16135908]

129. Dandona L, Dandona R, Gutierrez JP, Kumar GA, McPherson S, Bertozzi SM. ASCI FPP Study Team. Sex behaviour of men who have sex with men and risk of HIV in Andhra Pradesh, India. AIDS 2005;19:611-9. [PubMed: 15802980]

130. van Griensven F, Thanprasertsuk S, Jommaroeng R, et al. Evidence of a previously undocumented epidemic of HIV infection among men who have sex with men in Bangkok, Thailand. AIDS 2005;19:521-6. [PubMed: 15764858]

131. Frieden TR, Sterling TR, Munsiff SS, Watt CJ, Dye C. Tuberculosis. Lancet 2003;362:887-99. [PubMed: 13678977]

132. Zar HJ. Prevention of HIV-associated respiratory illness in children in developing countries: potential benefits. Int J Tuberc Lung Dis 2003;7:820-7. [PubMed: 12971664]

133. Manosuthi W, Chottanapand S, Thongyen S, Chaovavanich A, Sungkanuparph S. Survival rate and risk factors of mortality among HIV/tuberculosis-coinfected patients with and without antiretroviral therapy. J Acquir Immune Defic Syndr 2006;43:42-6. [PubMed: 16885778]

134. Sungkanuparph S, Manosuthi W, Kiertiburanakul S, Vibhagool A. Initiation of antiretroviral therapy in advanced AIDS with active tuberculosis: clinical experiences from Thailand. J Infect 2006;52:188-94. [PubMed: 15992932] 
135. Sharma SK, Kadhiravan T, Banga A, Goyal T, Bhatia I, Saha PK. Spectrum of clinical disease in a series of 135 hospitalised HIV-infected patients from north India. BMC Infect Dis 2004;4:52. [PubMed: 15555069]

136. Narain JP, Lo YR. Epidemiology of HIV-TB in Asia. Indian J Med Res 2004;120:277-89. [PubMed: 15520482]

137. Over M, Marseille E, Sudhakar K, et al. Antiretroviral therapy and HIV prevention in India: modeling costs and consequences of policy options. Sex Transm Dis 2006;33:S145-52. [PubMed: 17003679]

138. Ono S, Kurotaki T, Nakasone T, et al. Cost-effectiveness analysis of antiretroviral drug treatment and HIV-1 vaccination in Thailand. Jpn J Infect Dis 2006;59:168-73. [PubMed: 16785697]

139. Tupasi TE, Gupta R, Quelapio MI, et al. Feasibility and cost-effectiveness of treating multidrugresistant tuberculosis: a cohort study in the Philippines. PLoS Med 2006;3:e352. [PubMed: 16968123]

140. Floyd K, Arora VK, Murthy KJ, et al. Cost and cost-effectiveness of PPM-DOTS for tuberculosis control: evidence from India. Bull World Health Organ 2006;84:437-45. [PubMed: 16799727]

141. Baltussen R, Floyd K, Dye C. Cost effectiveness analysis of strategies for tuberculosis control in developing countries. BMJ 2005;331:1364. [PubMed: 16282379]

142. Islam MA, Wakai S, Ishikawa N, Chowdhury AM, Vaughan JP. Cost-effectiveness of community health workers in tuberculosis control in Bangladesh. Bull World Health Organ 2002;80:445-50. [PubMed: 12132000]

143. Schwartzman K, Oxlade O, Barr RG, et al. Domestic returns from investment in the control of tuberculosis in other countries. N Engl J Med 2005;353:1008-20. [PubMed: 16148286]

144. Gandhi NR, Moll A, Sturm AW, et al. Extensively drug-resistant tuberculosis as a cause of death in patients co-infected with tuberculosis and HIV in a rural area of South Africa. Lancet 2006;368:1575-80. [PubMed: 17084757] 


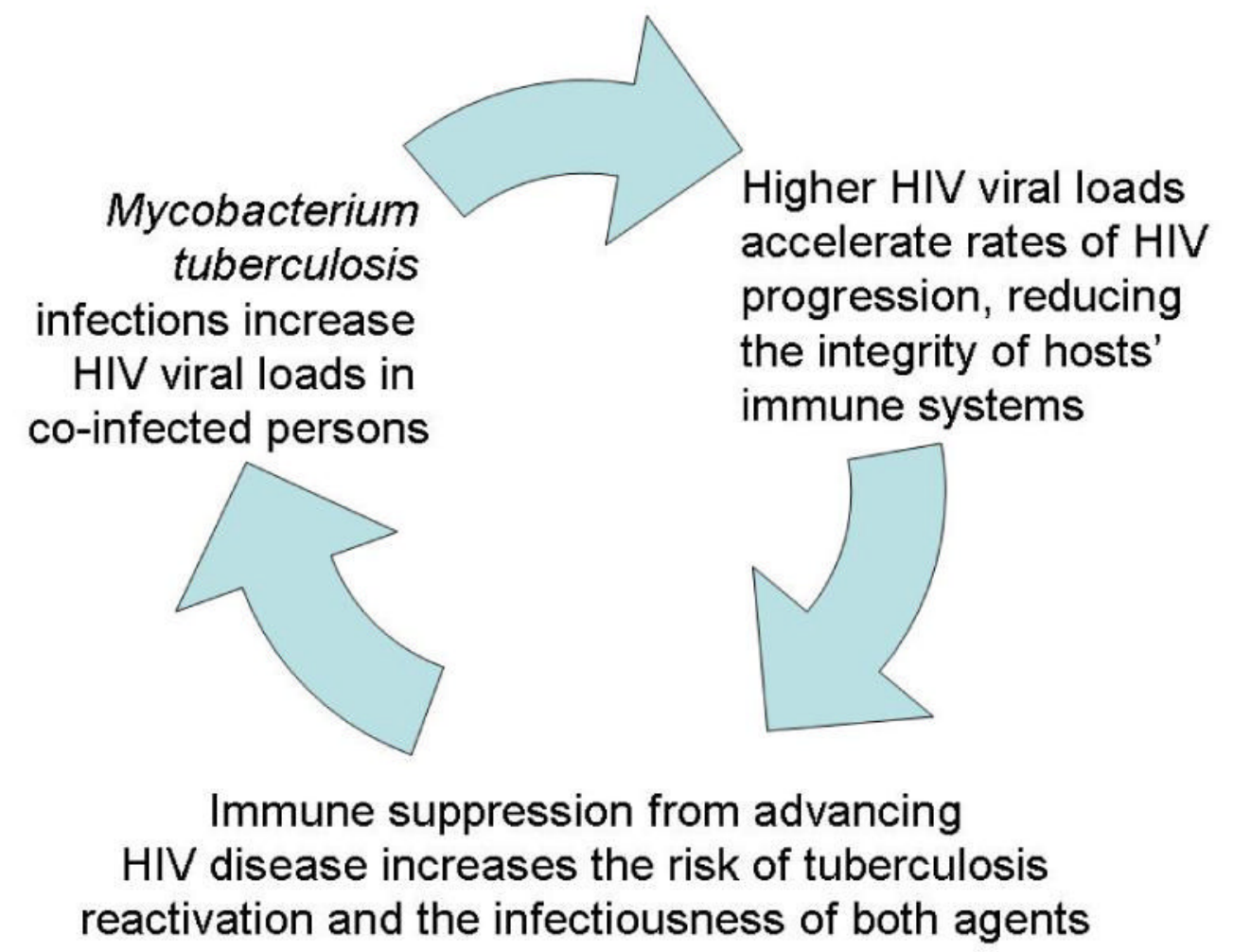

Figure 1.

The epidemiological synergy of human immunodeficiency virus (HIV) and tuberculosis. 


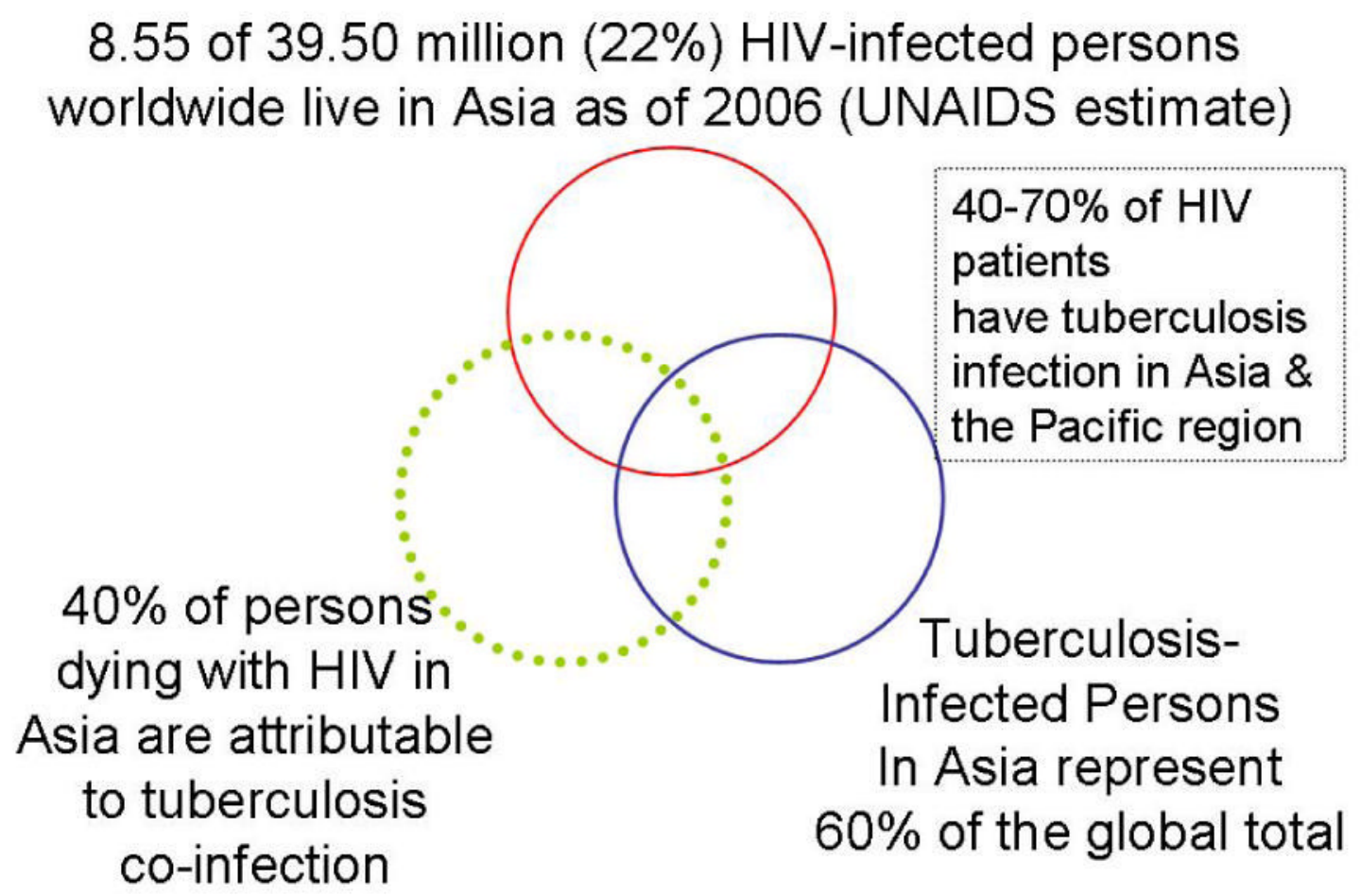

Figure 2.

The prevalence of human immunodeficiency virus (HIV) and tuberculosis co-infection in Asia. Estimates from UNAIDS and from reference 136. 


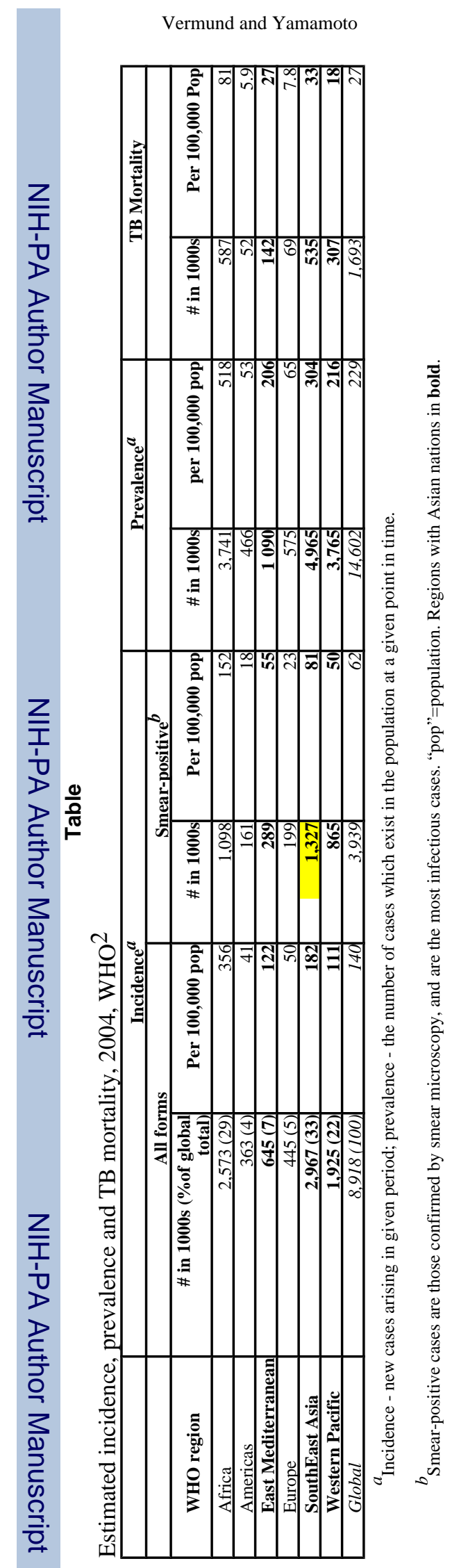

Tuberculosis (Edinb). Author manuscript; available in PMC 2007 October 16. 